\title{
Landscape Design of River Channels in Small Towns based on Regional Culture-Case Study of Landscape Design of Duohua River
}

\author{
Man $\mathrm{Lu}^{1,2}$, Chuyuan Wen ${ }^{1}$ and Chuanyue Wang ${ }^{1}$ \\ ${ }^{1}$ School of Civil and Transportation, Hohai University, Xikang Road, Nanjing, China. \\ ${ }^{2}$ School of Architecture, Southeast University, Sipailou, Nanjing, China.
}

\begin{abstract}
Water is the vital source of life while river channels constitute the arteries of the earth. As a key element of eco-structure of the Landscaping system, river plays a significant role in social life. Current river channels in small towns are managed only to achieve the traditional functions of flood prevention and irrigation while river channel landscape construction is confronted with problems such as replicating landscapes and degradation of ecological environment. River channel landscape should receive increasing attention after taking treatment measures including sewage interception, dredging, base soil treatment and revetment repair. This study offers ideas and strategies for landscaping designs of rivers in small towns that realize the value of regional culture in contemporary times on the basis of taking root in the concrete settings of the locations and the form of the design subjects in light of landscaping practices of Duohua River in Longli County which comb through regional elements and selectively keep some of them in the principle of respecting local history, natural conditions and culture in an effort to build a river landscape that represents regional culture and meets the requirements for sustainable development so that both the function and landscaping beauty can be better integrated.
\end{abstract}

\section{Introduction}

Current river channels in small towns are managed only to achieve the traditional functions of flood prevention and irrigation while river channel landscape construction is confronted with problems such as replicating landscapes and degradation of ecological environment. River channel landscape should receive increasing attention after taking treatment measures including sewage interception, dredging, base soil treatment and revetment repair. Compared with other countries, our country attaches importance to irrigation function of river channels but paid little attention to ecological environment construction. Recently with the increasing awareness of the importance of ecological balance and environment protection, the concept of ecological treatment of river channel gradually receives more attention. The treatment of river channel environment expands from mere treating water pollution to recovering ecological environment, wetland and ecological construction. However, the landscape design that integrates river channel treatment and landscape design remains at the experimenting stage. The article seeks to explore the application of urban river channel landscape design in real projects through real engineering examples.

\section{Regional culture and river channel landscape}

\subsection{The concept of regional culture}

The meanings of "region" are quite broad and can be classified in terms of national borders, weather patterns, ethnic cultures and etc. The boundary of region is determined by a particular shared characteristic. Therefore, the size of region varies. Culture, in broad sense, is the sum of material and spiritual achievement. Regional culture refers to the integration of natural landscape and history including its climatic conditions, topography, hydrogeology, flora and fauna, history, cultural, human activities, behaviours and etc. [1]. Regional culture is an organic whole that bases itself on the local traditional culture but actively absorbs foreign cultures.

\subsection{The scope of river channel landscape}

River channel, defined as the passageway of the river, refers to the entirety composed of river body, sandbars, beaches and the water across river shorelines. As the core of the river, it consists of three parts including river bed, mud flat and river terraces. Landscape refers to the combination of natural elements and cultural phenomena, the total of sights that from specific locations [2]. therefore, the landscape of river channel cannot be constituted by river alone but also the land area that interacts with the river as the core, generally referred to as the landscape within the radius of the river. The river 
channel landscape that is studied in this paper includes the river channel, buffer zone and the river bank slope [3]. Therefore, it is the regional complex composed of all natural elements and culture phenomena that are seen, heard and felt in the whole riparian zone.

\subsection{The importance of integrating regional culture with river channel landscape design}

The river in the city nourished humans living along its banks, pushing the progress of civilization of the society. The landscape elements of the banks contain abundant regional culture characteristics. However, in the context of globalization and cultural convergence, local culture and regional culture are bound to suffer different degrees of setback in their development. Current designers in China neglect the use of historical and cultural legacy and failed to settle down their minds and study landscape designs that feature local and regional features. Therefore, protecting and developing regional culture becomes ever more important in river channel landscaping practices. Amid current studies on river channel landscape design both at home and abroad, culture receives increasing attention with ideas of "rivers full of dynamics and culture", "river that reflects culture and new customs", "river featuring the balance of vegetation, water and culture" and etc. [4]. The formation of each river is accompanied by deep culture development. For the river channel landscape design to embody regional features, designers are required to materialize what is abstract and embody the regional culture as a whole so that such common ills as discontinuance of historical and culture ties and landscape convergence can be corrected and river landscape space that is full of vitality can be constructed.

\section{Location analysis of Duohua River of Longli of Guizhou}

\subsection{Geographic background of Duohua River of Longli of Guizhou}

Longli County, administered under Qiannan Buyi and Miao Autonomous prefecture of Guizhou Province, is located in the middle stretch of Miaoling Mountain range in the center part of Guizhou and also in the northwest of Qiannan Buyi and Miao Autonomous prefecture. Within the county, hills, low and average height mountains and river valleys are distributed in intervals from south to north. With neighbors of Guiding County, Fuquan County in the east, Huishui County in the south and Guiyang City in the west and north, it stands 1,080 meters above the sea level. It has a subtroFigureal monsoon humid climate with annual average temperature of $14.8^{\circ} \mathrm{C}$. By the end of 2012 , the total population of the county is 224,266 . It has multiple ethnic groups including Han, Buyi, Miao with ethnic minority of 91,754. The most famous tourist destinations in the county are Longjiashan Forest Park and Guan Mountain.

\subsection{Analysis of the planning of Duohua River of Longli of Guizhou}

In line with the principle of "treating the eco sensitive area with extra care", this paper proposes the idea of coexistence and thriving of urban development and regional culture- "sing praise to the landscape of Longli and restore the dynamics of the river".

Make the urban river system of Longli the bond that links fine tourist resource in Longli, the window through which Figureturesque scenery of small towns is displayed and the soil on which diverse ethnic group cultures thrive. Duohua River flows through the core section of the future new city and connects with national forest park. Fine river resources are valuable non-renewable resources. To protect the water quality and ecologic security of rivers in the city and realize its value, the old model of transforming rivers through engineering alone must be abandoned in planning.

By developing LID urban pipe network system, splitting rain from sewage, expanding the green area on both banks of the river and strictly managing the skyline and controlling on all other details, the future Duohua River becomes a "green waving zone" that circles the new Longli town where birds sing and flowers blossom. By connecting art gallery in the north, entrance to Longiia Mountain Forest Park, SenlinXipan waterfront town featuring local culture and Longjiashan Garden \& reservoir, Duohua River landscape corridor system featuring regional culture can be constructed.

\subsection{Analysis of status quo of Longli Duohua River of Guizhou}

The surrounding area, in general, has beautiful natural scenery with tableland and mountains that are rich in topographic changes, minor interference from human activity, dense vegetation, dams and alluvial flat that are atheistically pleasant to the eye. But in some areas, the vegetation is in disarray or the revetment is damaged with poor landscaping effects. After meticulous analysis, the main problems are (1) embankment: currently in a poor state with some damaged; (2) bridge: lack of exchange across the river while some bridges hamper flood discharge and lack in locally suitable forms;(3) water bodies: small size of water body in some areas with severe stony desertification; (4) water surface: monotonous water surface morphology and lack of wavy changes; (5) Shoreline: aesthetically unsatisfying skyline and scenery line; (6) buildings: lack of cultural ties between newly built buildings and existing ones and no cultural adherence.

\section{Regional strategies in landscape planning and design of Duohua River of Longli of Guizhou}

The regional strategy is formed on the basis of field research and surveying of Duohua river basin with landscape elements at all levels extracted in the principle of respecting the geographic textures of the field. 


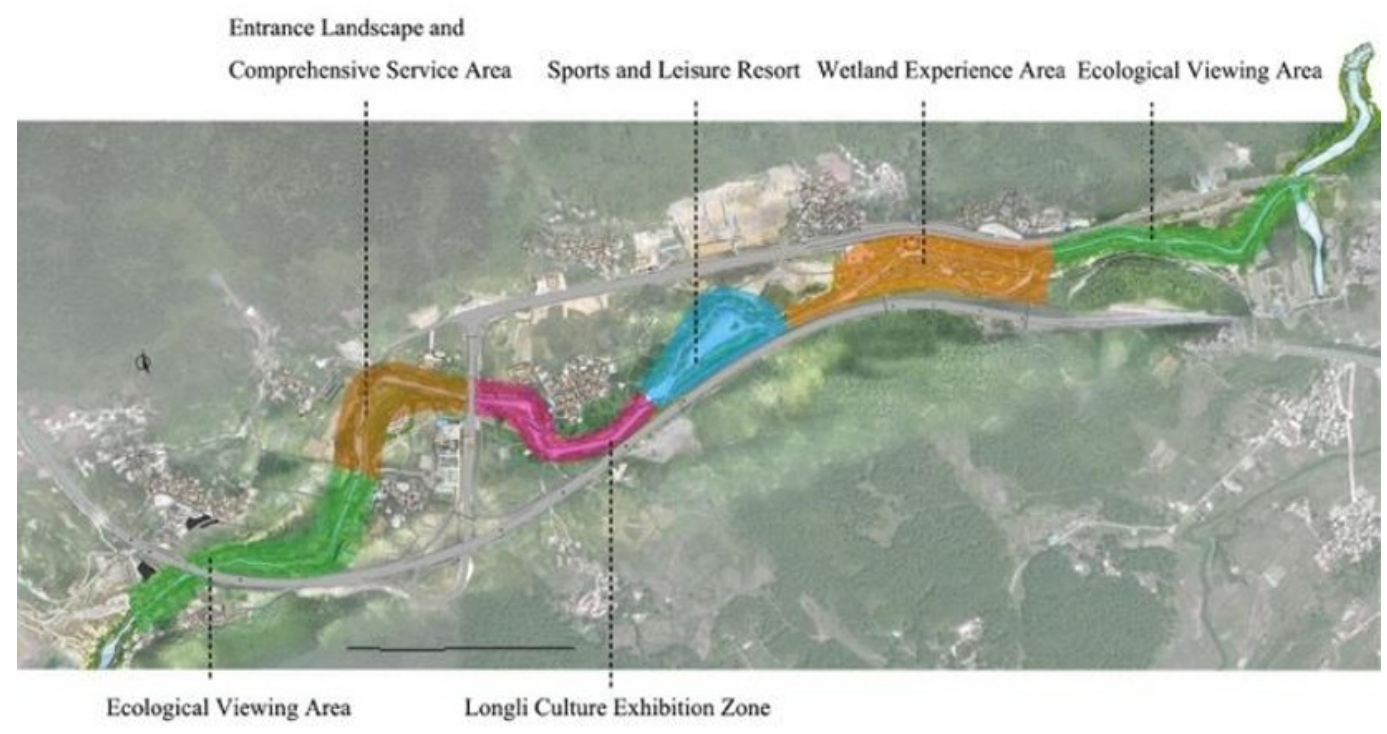

Figure 1. Landscape function zone chart

\subsection{The establishment of the theme of the landscape of Duohua river channel}

The theme of landscape design is the essence of the landscape of Duohua River. Not only the visual effects of the landscape need to be stressed, but also, more importantly, genius loci of the river channel must be brought out to reflect local culture. In the principle of keeping layout continuity and integrity, the themes of the sub zones should be determined by landscape structure, loci function, shoreline design and human behavior (Figure 1). Just as each symphony has a theme which is both the core and purpose of music, so does landscape design. To establish distinctive themes for each river section can help form culture axis with profound connotations in combination with local culture, so that people could have sense of pleasure and excitement as people move along the river and encounter different themes of landscape.

\subsection{Eco-friendly revetment design that respects local features}

Revetment is the basis of the landscape that surrounds the water body and also a critical component of the water conservancy and landscaping project. Firstly, the transformation of eco-friendly revetment is to meet higher standards of flood prevention. Local materials are used to treat the existing banks so that the embankment built earlier can be restored to a status that is nature friendly. Secondly, expand the water surface on both sides of river channel where conditions apply to overcome the shortcomings of hampering flood discharge and monotonous landscape so that the landscape space for both flood storage and sighting can be created. Thirdly, construct near-shore wetland space to smooth the shoreline where water space borders land area to achieve the dual functions of flood storage and adding landscape layers.
In light of the general requirements on the landscape of Duohua River, different revetment designs are adopted according to the cross section of the river channel. (1) Original type revetment: in sections where gradient is originally high or center area is large, consider keeping it in original status and consolidate the banks with the roots of aqua plants, as shown in Figure 2. (2) Natural type revetment: For sections where slope is steep and erosion is severe, not only grow plants, but also use local stones or wood for river bottom protection and enhance the ability of banks to fend off flood, as shown in Figure 3. (3) Oblique stone wall type revetment: in section where requirement on flood resistance is high and the center area small, gravity retaining wall must be built in a layer by layer approach. Then use materials such as reinforced concrete to make certain of its flood resistance ability on the basis of natural type revetment, as shown in Figure 4. (4) Steps stretching into water-type revetment: while ensuring flood resistance, water interaction space of the revetment varies as water level changes, as shown in Figure 5. (5) The viewing platform revetment: sightseeing platform combines with natural revetment, which ensures stability without causing major damage to its original look, as shown in Figure 6.

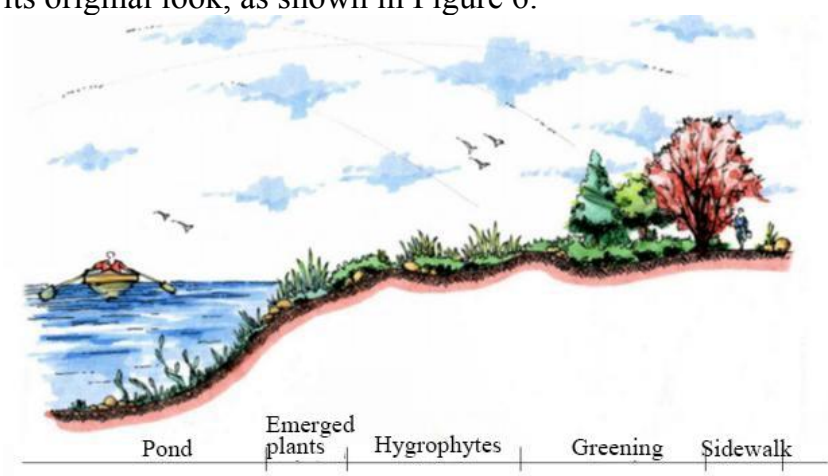

Figure 2. Original type revetment 


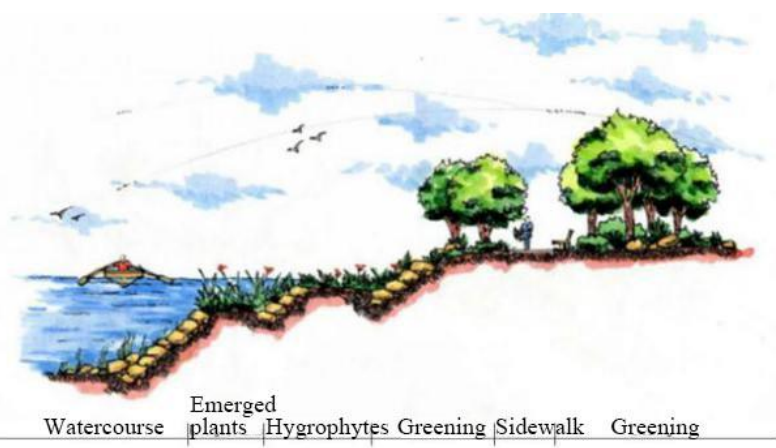

Figure 3. Natural type revetment

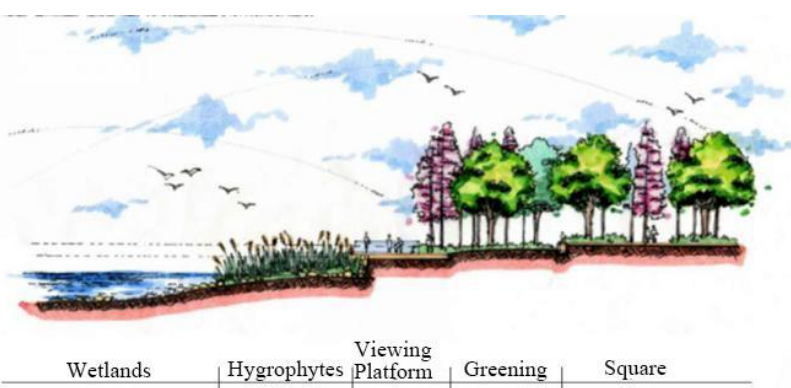

Figure 4. Oblique stone wall type revetment

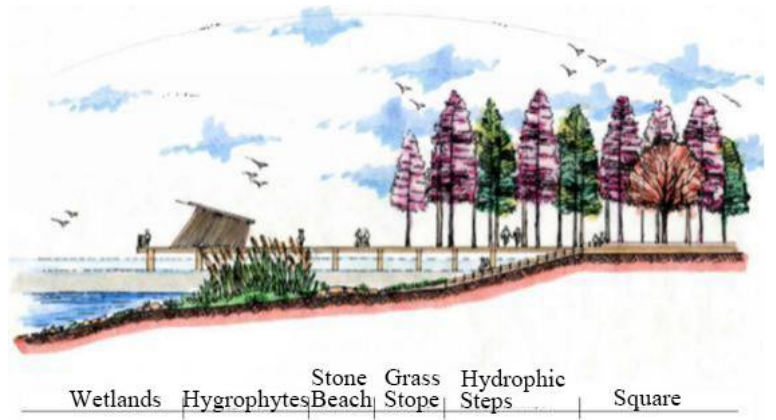

Figure 5. Sightseeing platform type revetment

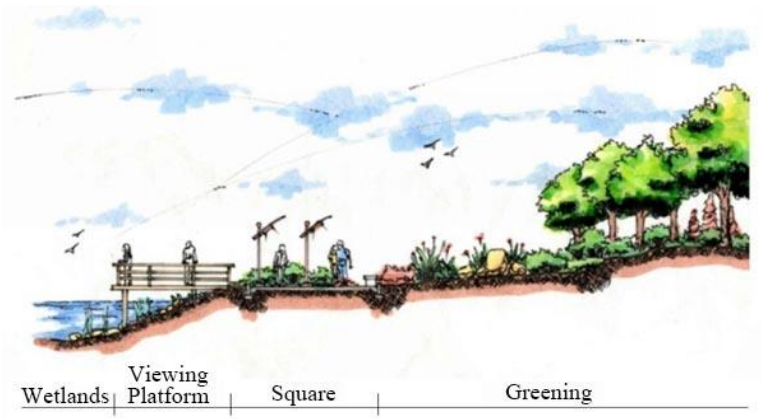

Figure 6. The viewing platform revetment

\subsection{Regional transformation of buildings}

The plane layout of buildings along the banks of Duohua river can be divided into three types: (1) Disperse type: with natural scenery as the dominant, buildings are distributed in clusters according to their functions so that they can integrate with the greater natural view as a whole; (2) Linear type: building complex is distributed along the shoreline. Also consider the combination and alternation of buildings with different function with special attention paid to sight line and skyline management. (3) Concentration type: in key areas of river channel, building complex is constructed with open space as the center to form building groups characteristic of the region so as to invoke a strong sense of belonging. To achieve that, manage the morphology of building along the banks from building skyline, sightline and morphology: (i) architecture skyline and sightline: as the margin of man-made landscape, the spatial form of skyline comes from the overlapping of the outlines of multiple clusters of buildings with those of the vegetation on mountains so that it becomes local architectural landscape; (ii) architecture morphology management: As a link in green infrastructure, the density and volume of buildings along the banks must be strictly limited to ensure small number of buildings and population and protect the ecological environment with due consideration on leaving the bottom of the building empty to save enough sight space for visitors to appreciate the river channel space together.

Furthermore, building in nearby villages of Duohua River should maintain the original architectural style that features the use of local materials such as wood and stones, as shown in Figure 7 Longli Mingju Residential Architecture. Given the functions and status quo of the existing buildings, different management practices are adopted, such as demolishing old buildings to restore the original look, transforming structure of the building where conditions apply and adopting the traditional facade design, cleaning the exterior facade and apply full scale of vegetation. Create local style buildings that both meet the needs of modern life and are rich in culture connotations such as buildings shown in Figure 8.

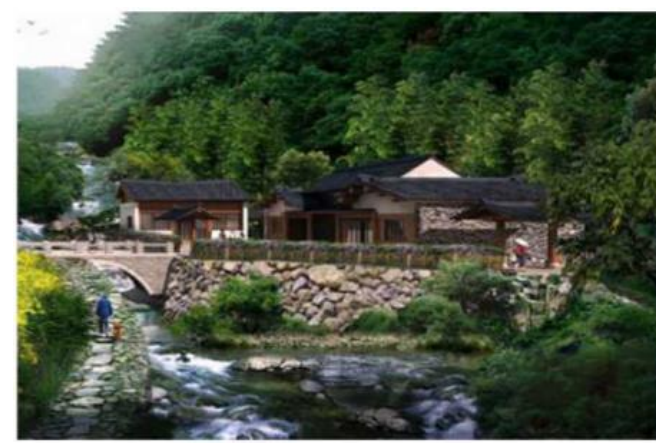

Figure 7. Longli Mingju Residential Architecture

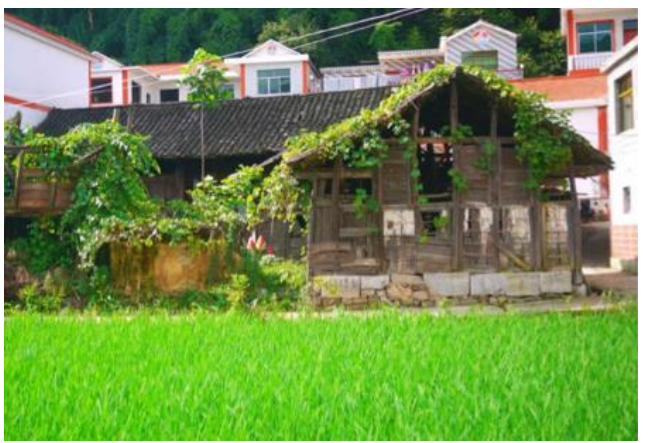

Figure 8. Longli Mingju Residential Architecture 


\subsection{Regional expression of landscape features}

Landscape features should be both entertaining and harmonious with the surrounding environment. Historic heritage must be protected. Local history, folk customs, art, religion, architectural style and even ethnic culture should be unearthed, understood and presented to materialize the abstract local culture, integrate culture into landscape and use landscape features to embody regional culture. Embody the artistic conception and theme through landscape features by certain artistic methods so as to make the landscape full of vitality. For example, the characteristic Tusi (system of appointing minority hereditary headmen) Culture of Longli (Figure 9 Tusi relic architecture sculpture) is presented through sculpture and other features displayed in cultural exhibiting zone in artistic methods including refinement and abstraction. Another example, Longli Wushan cave painting cluster is located near the living area of Wushan men of Guyuan Village of Gujiao Township of Longli County. It has in total more than 400 paintings stretching hundreds of meters with the size, number, themes, content, the rocks it covers boasting greatest in Guizhou. On the basis of protection of the authenticity of Wushan cave painting, the images on the cave paintings are adopted in designs of landscape features and barricades with the use of stones that are in abundance there. In addition, lotus roots are commonly seen in Duohua River which can also be conceptualized into a symbol and adopted in the design of interesting but live landscape features (Figure 10 Lotus root shaped landscape feature).

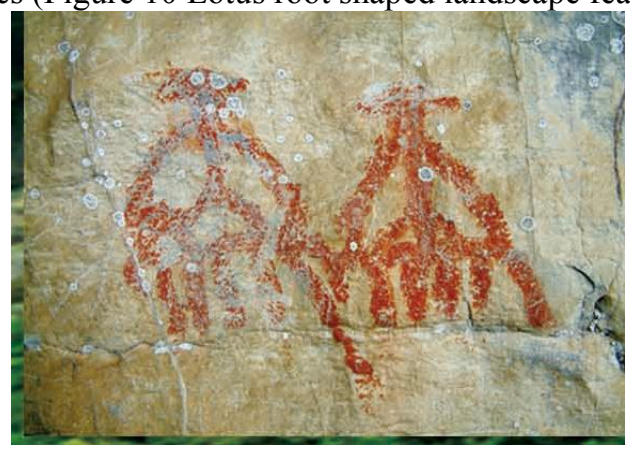

Figure 9. The characteristic Tusi Culture of Longli

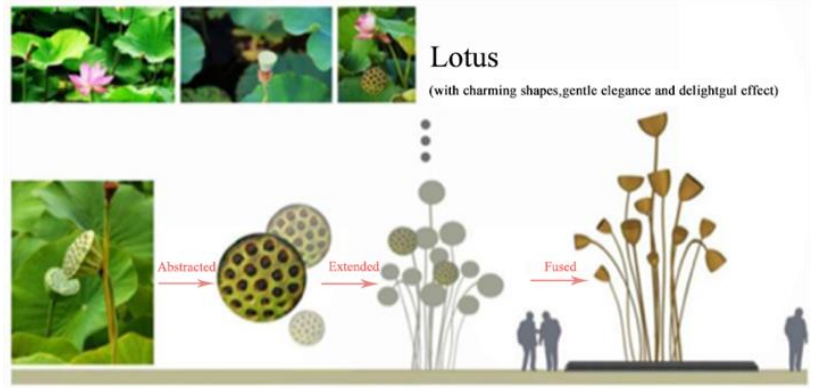

Figure 10. Lotus root shaped landscape feature

\subsection{Selections of regional plants}

Local plants are first choice when it comes to selection of plants in planning and design. Prior to this design, research and survey have already been conducted on existing aqua plants, plants living on the border of water and bank- solidifying plants. Vegetation that was damaged and contaminated is also restored. In addition, the growth of the individual plants and the stability of clusters must be taken into consideration when choosing the plant species for landscaping zone along the river banks. Plant species that are survival of the fittest in natural selection over a long term should be chosen while isolated or group planting are adopted based on the requirement of different microenvironment.

\section{Summary}

Landscape design is not merely rockeries and water design on the paper. More important agenda for the designers is to enable landscape to express local features, accurately interpret the loci and respect local culture in the context of accelerated urbanization. Many of the current landscape lacks in diversity of function usually with only visual effects achieved. Without local features and sense of loci, the landscape fails to interact with people and are reduced to negative space gradually, which leads to the eventual desolation of so called public open green space. This paper hopes waterfront landscape planning and design of Duohua River of Longli of Guizhou can set examples for future local landscaping projects and inspire more creative design concepts and more humane design thinking.

\section{References}

1. Man Lu, Chuanyue Wang, Landscape design of urban river channels based on regional culture-Case study of landscape design of Jiangdongzhi River in Xiaoshan of Zhejiang Province. J. Architecture and culture, 6, 79(2013)

2. Hamerton Philip.Landscape, (Roberts Publication, Boston 1885)

3. Gao Yang, Evaluation and Treatment Study on Ecological Situation of Rivers and Streams in Suburb Beijing: doctoral dissertation submitted to Beijing Forestry University (2009)

4. Chendong Zhu, Preliminary exploitation of landscape planning of river channels in major cities. J. Beijing Water Conservancy, 3, 7 (2002)

5. Anxia Wang, Hesheng Ye, Application of Regional Cultural Symbols in Urban Sculpture Design. J. Ability and Wisdom, 17, 194 (2010)

6. Fengbin Yuan, The Excavation and Figure of the landscape Feature of the Cities' waterfront Area. D. Wuhan University (2005) 